\title{
Batman, Trauma and the Self: The Hidden Narcissism Caused by Severe Trauma
}

\author{
Jae Yoon Jeong, ${ }^{1}$ Kang Joon Lee, ${ }^{1}$ Hyun Kim, ${ }^{1}$ and Jun-Seok Lee ${ }^{2}$ \\ ${ }^{1}$ Department of Psychiatry, Inje Unversity Ilsan Paik Hospital, Goyang, Korea \\ ${ }^{2}$ Healing-Tree Psychiatric Clinic, Goyang, Korea
}

\author{
배트맨, 외상 그리고 자기: 외상에 의해 야기된 나르시시즘의 문제 \\ 정재윤 ${ }^{1}$ 이강준 ${ }^{1}$ 김 현 ${ }^{1} \cdot$ 이준석 ${ }^{2}$ \\ 인제대학교 일산백병원 정신건강의학과, ${ }^{1}$ 치유나무정신건강의학과 ${ }^{2}$
}

Batman is one of the most often referenced movie characters in psychoanalytic inquires because of the character's complicated personality traits. Bruce Wayne, Batman's alter ego, is a rich bachelor who experienced parental loss during his childhood. With his eagerness for seeking vengeance, he becomes Batman, willing to fight evil personified. Many claim that the character of Batman in part, represents the major aspects of a traumatized neurotic personality, including a harsh superego, maladaptive defense mechanisms, and an unsolved homosexual tendency caused mostly by repressed patricidal fantasy. With this perspective, however, the majority of essential aspects of Batman remains unexplained. Since Kohut accorded great importance to the concept of the self, it has been widely recognized that childhood trauma has a profound impact on the stability of the self. Trauma makes the self incohesive and vulnerable in that the individual experiences a defective sense of self, an inability to modulate emotions, difficulty in modulating primitive fantasies, and disturbing alterations in relations with others. With the splitting of the self, demands of the self to develop are negated and repressed so that the self suffers from shame and emptiness. This causes outbursts of unsoothed aggression and anger in a quest for realizing the primitive and grandiose fantasy, which otherwise would have been channeled into more plausible goals. In terms of relationships and intimacy, the self tries to bond with seemingly powerful and almighty individuals whom it feels insecure without, and yearns for an idealized parental image throughout life. In this investigation, we chose the film $<$ Batman Begins $>$ as a source for the analysis since the film outstandingly depicts the core characteristics of what is occurring in the mind of the traumatized self. Through the analysis of Batman, we illustrate the effect of trauma on the self in terms of splitting, primitive affects, grandiosity, and idealizing tendencies.

Psychoanalysis 2020;31(2):23-33

KEY WORDS: Batman · Narcissism · Self · Trauma · Self psychology.

Received: December 27, 2019 Revised: March 1, 2020 Accepted: March 6, 2020

Address for correspondence: Jun-Seok Lee, MD, PhD

Healing-Tree Psychiatric Clinic, 307 Central plaza, 43-20 Jeongbalsan-ro, Ilsandong-gu, Goyang 10402, Korea

Tel: +82-31-903-0123, Fax: +82-31-903-0124, E-mail: mdjslee@yahoo.com

\section{서 론}

Breuer와 Freud(1893)가 히스테리에서 외상의 역할을 다 룬 이후 외상 개념은 수많은 변천을 겪어 왔다. 그것은 히스 테리의 주된 원인에서 전쟁 신경증의 발병 원인으로, 그리고 어머니와의 관계에서 아기가 경험하는 외상의 개념으로 이 어져 왔다. Freud는 외상을 기본적으로 해소되지 않은 성욕

This is an Open Access article distributed under the terms of the Creative Commons Attribution Non-Commercial License (https://creativecommons.org/licenses/by-nc/4.0) which permits unrestricted non-commercial use, distribution, and reproduction in any medium, provided the original work is properly cited.
이나 갈등의 문제와 연관 지었으며, 아동기의 외상이 지연된 작용(deferred action)을 통해 훗날 재경험되면서 여러 문제 를 일으킨다고 보았다. 심각한 외상적 경험이 자아로 하여금 불안을 느끼게 만들며 이를 정복하고 감쇄시키려는 자아의 노력을 유발시킨다는 것이다. Freud는 주로 신경증의 맥락 에서 외상의 효과를 다루었고, 이후의 작업은 후대 분석가들 의 몫으로 남겨졌다.

현대에 들어서 외상은 신경증의 분석에만 국한되지 않고, 다양한 자아의 상태들 및 방어와 관련하여 중요한 주제로 다루어지고 있다. 특히 Freud(1926)가 어머니와의 관계에서 아이가 겪는 외상을 다룬 이후로, 분석가들은 부모의 양육 
또는 상실과 관련하여 아이가 겪는 외상 및 그 영향에 대해 분석하기 시작했다. 최근 Beiser(2013)는 Burchfield라는 예 술가의 사례를 통해 조기 부모 상실이라는 외상적 경험이 그 의 예술 세계에 미친 영향을 분석하였으며, McDougall(1986) 은 이러한 외상이 자기 처벌 또는 공격성 조절의 문제를 야 기할 수 있음을 보여주었다. Blum(1983)은 조기 부모 상실 과 분열(splitting) 사이의 관련성을 다루었다.

부모의 상실이라는 외상적 경험은 영화에서도 반복적으 로 다루어지는 주제이다. 특히 미국 영화 시장을 중심으로 양산되고 있는 슈퍼 히어로물들은 부모 또는 주 양육자의 상 실과 그로 인해 영웅들이 겪는 심리적 고통 사이의 관계를 보 편적으로 보여주고 있다. 그런 맥락에서 슈퍼 히어로 영화 속 인물들은 분석의 적절한 소재가 되는데, Kang과 $\mathrm{Yu}(2019)$ 는 어린 시절 부모를 상실하고 방황하는 〈가디언즈 오브 갤럭시〉 라는 영화 속 주인공을 분석함으로써 아들이 가진 부친 살해 의 환상 및 그로 인한 죄책감과 우울의 문제를 다루기도 하 였다.

본 논문은 2005년 개봉한 〈배트맨 비긴즈〉라는 영화를 주 텍스트로 삼아서 조기 부모 상실이라는 외상을 다루고자 한 다. 배트맨은 다른 슈퍼 히어로에 비해 그 역사가 깊고 정신 분석의 영역에서 종종 다루어졌던 캐릭터이다(Bass 2009; Brody 1995; Novy 2008; Lang 1990; Langley 2012; Reichstein 1998; Wertham 1972). 그동안 많은 분석가들이 외상이 배트맨의 자아 취약성과 방어에 미친 영향에 대하여 분석하 였으나, 외상이 자기(self)나 성격 구조에 미치는 영향에 대해 서는 선행연구가 드문 상황이다. Psychodynamic Diagnostic Manual의 제2판(PDM-2)(Malberg와 Rosenberg 2017)에서 는 외상, 특히 아동기 외상이 개인의 삶 또는 자기(self) 그리 고 자아의 발달에 큰 영향을 미치며, 외상의 효과는 성격적 인 차원에서 주로 Cluster B Personality와 연관된다고 밝히 고 있다. 하지만 Zepinic(2016)은 외상에 대한 평가와 진단 체계의 발전에도 불구하고, 외상이 자기와 성격 구조에 미치 는 영향에 대해서는 아직 연구가 부족하다는 점을 지적하였 다. 이에 본 논문은 배트맨 그리고 그 가면의 배후에 있는 브 루스 웨인이라는 캐릭터를 통하여 외상이 자기의 개념 및 성 격 구조에 미치는 영향을 자기심리학 및 상호주관성 관점에 서 분석하였다.

\section{본 론}

\section{<배트맨 비긴즈>의 줄거리}

영화는 주인공인 브루스 웨인이 꿈을 꾸는 장면으로 시작 한다. 꿈속에서 그는 단짝 친구 레이첼과 숨바꼭질을 하고 놀
던 어린 시절을 반복한다. 놀이 도중 그는 실수로 동굴 안에 빠지고, 거기서 그가 가장 두려워하고 공포스러워하는 존재 인 박쥐 떼를 마주하게 된다. 이후 영화는 그가 박쥐를 공포 스러워할 수밖에 없었던 이유를 차근차근 보여준다. 브루스 웨인의 아버지 토마스 웨인은 고담시(市)의 대부호로 자신 의 이름을 본뜬 웨인 사(社)를 설립한 뒤 경영진에서 물러나 의사로서의 본업을 이어나가고 있다. 그는 기업이 벌어들인 수익으로 철도를 개설하거나, 도시 구빈책에 앞장서는 등 시 민들의 안녕을 위해 힘쓴다. 고담 시민들은 물론 그의 아들 인 브루스 웨인에게도 아버지 토마스 웨인은 존경스럽고 본 받을 가치가 있는 인물이다. 브루스 웨인이 문제의 박쥐 떼 의 습격을 받고 난 며칠 뒤 웨인 씨 가족은 오페라 〈메피스토 펠레〉를 보기 위해 집을 나선다. 관람 중 무대에서 박쥐의 형 상을 한 배우들이 등장하자 브루스 웨인은 소스라치게 놀라 며 아버지에게 묻는다. “나가면 안 될까요? 제발요." 토마스는 바로 아들과 아내를 데리고 극장을 나선다. 그리고 바로 그날 밤, 웨인 부부는 브루스 웨인이 보는 앞에서 살해를 당한다. 토마스가 평생 동안 그토록 돕고 싶어 했던, 고담시 뒷골목의 빈민에 의해서 말이다. 경찰서로 인도된 브루스 웨인은 공포 와 불안에 어쩔 줄 몰라 하고 있다. 겁에 질린 소년 브루스 웨 인을 보고 경사 고든이 다가와 코트를 덮어주며 그를 다독인 다. 그는 고담시의 몇 안 되는 청렴한 경찰관 중 한 명이다. 극심한 트라우마를 겪은 소년 브루스를 끌어안은 또 다른 인 물은 바로 집사 알프레드다. 그는 부모님을 잃은 소년 브루 스의 친구이자 양부모 역할을 맡게 된다. 이후 영화는 그의 청년 시절로 건너뛴다. 그는 명문대에 입학하지만 학교에 적 응하지 못한다. 모든 부를 물려받았지만 부모의 상실로 인한 상처는 그에게 씻을 수 없는 절망과 복수에 대한 열망을 남 긴다. 청년 브루스는 고향으로 돌아와 이제 막 형기를 마치 고 나온 살해범을 총으로 쏴 죽이려 한다. 그러나 아이러니 하게도 그는 브루스가 보는 앞에서 다른 청부업자의 손에 의해 살해당한다. 과거의 상처를 회복시킬 수 있으리라 믿었 던 유일한 방법, 즉 복수마저 실패한 뒤 브루스는 참을 수 없 는 무력감과 절망에 휩싸인다. 이후 그의 방황이 시작된다. 그는 돌연 도시를 떠나 빈민의 무리에 섞여 좀도둑질과 패 싸움을 일삼는다. 선과 악의 구분마저 흐려진 그에게 유일한 목표는 보다 강한 신체를 갖는 것, 따라서 모든 악에 맞서 싸 울 수 있는 능력을 획득하는 것이다. 외딴 나라에서 수감 생 활을 반복하며 그저 싸움에 눈이 멀어 있던 브루스에게 어 느 날 한 남자, 라스 알 굴이 찾아와 목적 없이 싸움을 벌이지 말고 악의 처단과 정의 구현을 위해 함께 싸우자고 말한다. 언제나 자신을 지도해 줄 강한 누군가를 필요로 했던 브루 스는 그를 따라 산으로 올라가 혹독한 수련을 받는다. 브루 
스는 누구보다 뛰어난 제자가 되지만, 무자비하게 살인을 일 삼는 라스 알 굴의 방식에 동의하지 못한다. 결국 두 사람은 싸움을 벌이게 되고, 모든 건물이 불탄다. 브루스는 기절한 라스 알 굴을 남겨둔 채 산을 내려와 고담시로 귀환한다. 브 루스는 라스 알 굴이 알려준 다양한 전투 기술을 활용해 고담 시의 악을 근절하고자 한다. 집사 알프레드, 경찰관 고든, 웨 인 사의 응용과학부장 폭스는 그가 뜻을 이루도록 돕는다. 이 들은 모두 청렴하고, 정직하며, 신의를 가진, 브루스가 믿을 수 있는 사람들이다. 브루스는 어떤 악당이라도 공포에 떨 수 밖에 없는 강력한 상징이 되고자, 자신이 그토록 두려워했던 박쥐의 형상을 본뜬다. 그리고 그렇게 가면 쓴 밤의 기사로 거듭난다. 배트맨은 고담시의 악당들을 소탕하기 시작하는 데, 그러던 중 모든 것의 배후에 라스 알 굴이 있다는 것을 깨 닫고 그와 최후의 결투를 벌인다.

\section{기존의 입장들}

그동안 많은 저자들은 배트맨의 자아와 방어기제 발달의 측 면에서 외상의 중요성을 강조하였다(Bass 2009; Brody 1995; Langley 2012; Reichstein 1998). 이들은 브루스 웨인이 겪 어야 했던 조기 부모 상실이 부친 살해의 욕망을 자극함으로 써 과도한 죄책감을 유발시키거나, 조절되지 않은 나쁜 충동 들이 범죄에 대한 처벌 의지로서 승화된다고 보았다. 이런 관 점에서 이들은 배트맨이 욕동을 통제하고 억압하기 위해 다양 한 방어기제들을 발달시키고, 그런 측면들이 결국 배트맨의 영웅적 면모를 형성했다고 주장하였다. 특히 Langley(2012)는 숙부를 직접 처단하지 못하고 머뭇거리는 햄릿과 배트맨의 공통점을 탐색하면서, 부친 살해 욕망을 자극당한 배트맨의 무의식이 부모의 살해범을 직접 처단하는 대신 치환(substitution)을 통해 보편적인 악에 대한 처벌 의지를 보이는 것이라 고 주장하였다. 다른 한편으로 $\operatorname{Brody}(1995)$ 는 1976년 미국에서 벌어졌던 차우칠라(Chowchilla) 사건(26명의 아이들이 납치되 어 땅 구덩이에 갇혀 있다가 구출된 사건)의 생존자들과 배트 맨 사이의 심리적 유사성을 분석하였다. 그에 따르면 이 사건 당시 생존했던 아동들 중 몇 명은 외상 이후 전능한 영웅 판타 지에 빠졌는데, 심지어 그중 하나인 $\mathrm{Bob}$ 은 이에 심취해 총격 사건을 저지르기도 하였다. Brody는 외상 이후 Bob의 자아가 취약해지면서 자신을 납치했던 공격자와의 동일시가 나타났 다고 주장하였다. 그는 또한 Bob에게서 외상을 보상하기 위한 영웅 판타지가 나타났다고 설명하면서 이것이 배트맨의 심리 와 큰 유사성을 보인다고 분석하였다.

이처럼 기존의 많은 분석가들은 자아 취약성, 공격적 충동 혹은 초자아의 문제를 중심으로 전통적 관점에서 배트맨의 심리를 다루었다. 하지만 최근 자기심리학 혹은 상호주관성
이론의 관점에서 외상의 심리적 영향에 대한 새로운 관점이 제시되고 있다. 가령 Hagman(2016)은 부모 상실이라는 외 상을 자기애적 상처라는 개념과 연계하여 상기한 저자들과 는 다른 관점을 보여주었다. 그에 따르면 어린 시절 부모를 상실한 사람들은 자기대상(selfobject)의 적절한 공감을 받 지 못해 결국 타인으로부터 철수된 상태에서 감정적으로 무 디고 냉철한 반응을 보이는데, 이로 인해 타인의 존재를 인정 하기를 거부하는 상태까지 이르게 된다. Stolorow(2018)도 외 상이 자기의 개념에 근본적인 영향을 미침으로써 결국 타인 과 타인을 포함한 세계 자체에 근본적인 변화를 가져온다는 점을 강조하였다. 그는 Heidegger의 현존재(Dasein)라는 현 상학적 개념을 참조하여 외상이 근본적으로 뒤틀어버리는 세 계에 대해 기술하였는데, 이것은 취약한 자아의 세계라기보다 는 근본적으로 좌초되고 난항에 빠진, 절망적(hopeless)인 세 계를 말한다. 여기서 자신과 타인을 포함한 이 세계라는 것은 자아보다 더 넓은 외연을 가지고 있다. Stolorow는 Heidgger 의 맥락(context) 개념을 차용하여 이런 개념을 설명하였다. 외상은 언제나 맥락의 형태로 발생하는 것이지, 대상과 자 아가 구별된 상태에서 자아에만 발생하지 않는다는 것이다. Heidgger의 존재(Being)가 거주하는 세계처럼, Stolorow의 세계 또한 자아와 타자 또는 대상이 명백하게 구분되는 세계 가 아니다. Stolorow는 주체와 대상 사이의 구별이라는 서양 철학사적 맥락을 비판했던 Heidegger를 참조하면서, 외상을 세계 또는 그것의 일부인 자기대상과의 항구적인 상호관계 속에 있는 자기의 관점에서 재사유할 것을 권고하였다. 본 논 문은 이런 세계 또는 맥락의 개념을 이해하기 위해서 그것의 중심에 있는 자기(self)의 개념에 대해 먼저 살펴보고자 한다.

\section{자기의 개념}

자기의 개념을 처음으로 고안한 Kohut은 전통적인 분석 방식으로 잘 치료되지 않는 환자들을 대하면서 새로운 개념 의 필요성을 느꼈다. 그는 오로지 자신에 대한 관심만으로 가득 차 있는 것 같으면서도 매우 취약하고 우울한 환자들을 보았는데, 이들은 분석가가 자기애적 구조를 포기하라고 설 득할 때마다 심한 부적절감과 모욕감을 느끼곤 하였다. 이들 은 겉보기에는 자기 자신에 과도하게 몰두하는 것처럼 보였 지만, 분석을 진행할수록 실제로는 자신을 반영해 주고 공감 해 줄 타인을 매우 필요로 한다는 사실이 드러났다(Mitchell 과 Black 1995).

Kohut(1977)에 따르면 자기란 성격의 중심 영역을 형성하 는 것으로, 그것은 공간 안에서 그리고 시간의 연속 안에서 우리가 하나로 통일된 신체와 정신에 대한 감각을 갖게 하 는 것이다. 이것은 우리로 하여금 스스로를 주도권과 지각의 
독립적인 중심으로 느낄 수 있도록 해준다. Kohut(1971)은 대상관계와 별개로 자기애의 발달 과정을 설정하여 자기의 발달을 묘사하였다. 그에 따르면 생후 초기 아기는 파편화된 자기를 갖고 태어나는데, 이는 적절한 양육 과정을 거치면서 보다 응집된 자기로 발달하게 된다. 자기는 양극적인 특성을 갖는데, 한쪽은 고태적 과대자기(archaic grandiose self)의 극 으로 불리며 다른 한쪽은 이상화 부모 이마고(idealized parental imago)의 극이라고 불린다. 여기서 주 양육자가 자기 대상(selfobject)으로 양극적인 아기에 대해 반영해 주고 공 감해 줌으로써, 고태적 과대자기의 극이 점차 야망으로 발달 하고 이상화 부모 이마고의 극이 점차 이상과 목표로 발달할 수 있도록 돕게 된다. 그런데 이 자기대상은 자기와 완전히 구별된 타인으로 존재하는 것이 아니라, 자기의 발달의 일부 분으로 자기 성장에 적극적으로 참여하는 역할을 하게 된다.

여기서 '자기대상'이라는 개념이 어째서 '자기'의 개념 안에 포함되는지 의문이 따를 수 있다. 자기라는 것은 대상(object) 의 반대 개념이 아니다. 이는 Kohut이 후기에 자기-대상 (self-object)이라는 용어를 자기대상(selfobject)으로 변경한 이유와도 상응한다. Stolorow와 같은 상호주관성 이론가들 이 주체와 대상 사이의 구별 이전의 맥락 또는 세계를 다루 고자 했던 Heidegger의 철학적 개념들에 이끌렸던 것도 같 은 이유 때문이다. 우리는 우리와 다른 타인을 대면할 때, 그 를 우리와 완전히 구별된 것으로 경험하는 동시에 우리 자 신의 일부로써 경험하기도 한다는 것이다. 대상이 전자와 유 사하다면 자기대상이란 후자와 유사한 것이다. McWilliams (2011)는 자기대상이라는 용어에는 '자기대상의 역할을 하는 사람은 자기의 바깥에 있는 대상인 동시에 자기 정의(selfdefinition)의 일부로 기능한다는 뜻이 담겨 있다'고 하였다.

리비도의 관점에서 자기 자신에 대한 리비도의 증가는 반 드시 타인에 대한 리비도의 상대적 감소를 수반하지 않으며, 오히려 자기의 발달은 타인을 향한 대상 사랑의 발달을 수 반할 수 있다. Kohut(1971)은 자기애적 환자의 분석이 진행 되면 대상 사랑 능력이 확장된다고 하였다. 그것은 자기애가 대상 사랑으로 변하는 것이 아니며 대상-리비도의 유용성 이 증가하기 때문에 일어나는데, 첫째로 이상화 리비도의 유 용성이 커짐으로써 이미 존재하는 대상 추구가 보다 세련되 면서 심화되고, 다음으로 퇴행적 자기애의 벽 뒤에 숨겨져 있어서 사용할 수 없었던(억압되었던) 대상-리비도가 자유 로워지며, 마지막으로 더욱 튼튼해진 자기의 응집성을 통하 여 자아의 능력이 강화되어 대상 사랑에 집중적으로 관심을 갖는 능력이 증가하는 방식으로 일어난다. 이런 맥락에서 $\mathrm{Ko}^{-}$ hut(1971)은 '자기애의 반대 명제는 대상관계가 아니라 대상 사랑이다'라고 말한 바 있다. 이는 자기애와 대상관계의 발
달 과정이 양립하며, 각각 독립적인 발달 궤적을 따르지만 서로 영향을 미친다는 것을 의미한다.

Mahler(1975)가 공생기와 관련해 기술한 바 있듯이, 초기 에 아기는 자신과 양육자를 분리된 존재로 경험하지 못한다. 그래서 자신의 의도대로 세계가 움직인다는 전능 환상에 사 로잡히는데, 자기대상은 이와 유사한 가설에 뿌리를 두고 있 다. 자아가 대상과의 관계 속에서 발달한다면, 자기는 자기 와 구별되지 않는 자기대상과의 관계에 의거해 조금씩 발달 하게 된다는 것이다. Kohut(1971)에 따르면 자기는 발달 과 정에서 필연적으로 좌절을 경험할 수밖에 없다. 앞서 기술한 아기의 관점을 따르자면, 아기는 본래 이 세계가 사실은 자 신의 전능함으로 모두 통제되지 않는다는 뼈아픈 진실을 깨 달아야만 하는 운명에 놓여 있다. 생애 초기에 아기는 주 양 육자라는 자기대상을 마치 자기의 일부인 것처럼 여기다가 점차 그 자기대상이 자기의 것이 아니라는 사실을 깨닫게 되면서 그 주 양육자 혹은 자기대상의 기능을 자신의 일부로 내재화시킨다. 이러한 내재화는 그것이 기원하는 곳으로부터 전혀 다른 곳, 즉 주 양육자에게서부터 자기 안으로 옮겨지면 서 이루어지기 때문에 필연적으로 변형의 과정을 거칠 수밖에 없다. 그래서 Kohut(1971)은 이를 '변형적 내재화(transmuting internalization)'라고 불렀다. 어떠한 사태라 할지라도 변 형되기 위해서는 그에 합당한 적절한 시간을 필요로 하는데, 이는 자기대상의 경우에서도 마찬가지다. 좌절은 용납 가능 한 범위에서 천천히 이루어질 수도 있고, 그 범위를 넘어서 는 수준으로 급속하게 일어날 수도 있는데, Kohut(1971)은 전자만을 '최적의 좌절'이라고 불렀다. 그는 최적의 좌절을 넘어선 경우에는 변형적 내재화의 실패가 발생하고 그에 따 라 성숙하지 못한 양극적 형태의 자기 수준에서 정체되는 결과가 나타난다고 보았다. 그리고 이로 인해 타인에 대한 과도한 이상화 및 평가 절하, 자기의 과대성의 표현 및 공허 감이 나타나게 된다고 설명하였다.

\section{외상의 문제}

Zepinic(2016)은 외상적 경험이 피해자의 자기-응집성과 자기-연속성을 영원히 변경시킬 수 있음을 지적한 바 있다. 그는 외상 입은 개인들이 취약하고 결함 있는 자기에 대한 감각과 관련된 염려를 보이는 한편, 자신의 와해된 자기가 자신뿐 아니라 타인들에게 위협이 된다고 여기며, 침습적 기 억과 플래시백, 그리고 꿈에 압도된다고 언급하였다. 그에 따르면 자기의 손상은 신체의 수준뿐 아니라 정동, 신념과 이상, 대인관계의 차원에서도 기술될 수 있다. 또한 외상을 입은 개인은 외상이 발생한 당시의 압도적인 자극을 회피하 기 위해 필연적으로 미숙한 생존 전략들을 택하게 되는데, 
외상이 발생한 지 한참 지나고 나서도 여전히 미숙한 전략 에 얽매인 채 살아가는 모습을 보인다.

앞서 언급했던 Stolorow(2018)는 외상이 개인을 본래적 죽음을-향한-존재(authentic being-toward-death)의 형태 로 곤두박질치게 만든다고 주장하였다. 그는 외상이 본래적인 죽음을-향한-존재를 폭로시키며, 평범하고 평균적인-매일의 선형성과 시간성, 과거로부터 열린 미래를 향해 펼쳐져 늘어 서 있는 것에 대한 감각을 파괴시킨다고 하였다. 그는 외상 의 경험이 영원히 현존하는 것처럼 얼어붙어서, 개인이 영원 히 그것에 붙잡힐 수밖에 없는 저주에 걸린다고 설명하면서, 외상의 영역에서 모든 지속의 감각은 붕괴되고, 외상적 과거 는 현재가 되며, 미래는 그저 영원히 반복될 뿐이며 그 외의 모든 의미를 잃게 된다고 하였다. 외상은 시간성의 보편적이 고 공유된 구조를 너무도 심각하게 변형하기 때문에, 외상을 입은 사람은 말 그대로 굉장히 다른 종류의 현실을 살아가 며, 타인들의 세계와 비교 불가능한(incommensurable) 것으 로 느껴지는 경험적 세계에서 살게 된다. 이런 비교 불가능 성은 결국 다른 인간 존재로부터의 소외와 소원함을 야기시 킨다. 여기서 극심한 감정적 외상의 경험은 맥락적 경험으로, 거기에는 어떠한 진단적 실체도 없고, 오직 황폐화된 맥락들 만이 존재하게 된다.

배트맨에서 자기의 손상 역시 비슷한 관점에서 다루어 볼 수 있다. 브루스 웨인은 계속해서 박쥐로 대변되는 외상적 상징물을 침습적으로 재경험하는 경향을 보인다. 라스 알 굴 이 제공한 환각물질에 의해서나 꿈을 통해서 그는 박쥐를 재경험하는데, 여기서 박쥐는 초기의 외상을 환기시키는 공 포스러운 존재로서 브루스 웨인을 압도한다. 그는 자신이 약 하다는 생각에 끊임없이 자신의 신체를 단련시키는 한편 자 신이 이상화시키는 자기대상의 힘을 갖고자 갈망한다. 정동 의 차원에서 브루스 웨인의 주된 정서들 가운데 하나는 분노 인데, 이러한 분노가 그로 하여금 악당들에 대한 복수심을 유 지시키는 역할을 한다. 대처 전략이라는 차원에서 볼 때 브루 스 웨인이 경찰이나 검사가 되는 대신 직접 가면 쓴 기사가 되는 방식 역시 성숙한 방식인지 의문을 제기할 수 있다. 자 기의 와해라는 관점에서 보면 이런 대처 전략은 미성숙한 자 기 및 그것과 결부된 환상들로부터 유발된 미숙한 해결책이 라고 간주할 수 있다. 이런 관점들을 종합하여 본 논문에서는 배트맨에서 자기의 손상이라는 문제를 크게 네 가지 관점에 서 다루고자 한다. 첫째는 정체성의 문제 및 분열, 둘째는 정 동 조절의 문제, 셋째는 환상의 문제, 넷째는 관계의 미성숙 함, 그중에서도 특히 이상화의 문제를 다룰 것이다.

\section{정체성의 문제와 분열}

배트맨이라는 캐릭터는 여러 측면에서 분열(splitting)의 기제를 보여준다. 밤만 되면 가면을 쓰고 나타나 전혀 다른 정체성을 가지고 활동하는 브루스 웨인의 모습은 그 자체로 분열된 정체성을 암시한다. 이와 상응하여 그가 거주하는 공 간도 분열되어 있다. 브루스 웨인이 거주하는 호화스러운 대 저택의 지하에는 배트맨의 생활 공간인 동굴 배트케이브가 있다. 〈배트맨 비긴즈〉가 그리는 고담시의 모습 또한 분열 되어 있다. 브루스 웨인이 부모를 상실하기 전 고담시는 희 망에 찬 산업도시로서의 면모를 보인다. 브루스 웨인이 부모 님과 함께 전철을 타고 가는 장면에서 창 밖에 비친 고담시 는 맑은 하늘 아래 반짝반짝 빛나는 마천루의 위용을 과시 하고 있다. 호기심 많은 브루스의 질문에 점잖고 지적인 아 버지 토마스 웨인은 친절한 답변으로 응한다. 부모가 살해된 뒤에도 경찰들은 발 빠른 대처로 범인을 잡아내고, 고든 경 감과 알프레드는 슬픔에 빠진 브루스를 보듬어 준다. 그러나 아버지 사망 후 오랜만에 고향에 돌아온 브루스는 완전히 달라진 고담시를 마주하게 된다. 법은 제 기능을 잃었고, 곳 곳에 빈자들과 폭력배들이 넘쳐난다. 객관적인 대상으로서 의 고담시 자체는 그대로지만, 영화는 어둡고 칙칙한 톤으로 타락한 고담시를 표현한다. 선량한 고든 경감은 좌천되었고, 부패한 경찰과 행정가, 검사들이 도시를 지배하고 있다. 도 시 곳곳에 정신질환자들이 넘쳐나고, '아캄 수용소'라는 시 설만이 이들을 간신히 사회로부터 격리시키고 있다.

Reichstein(1998)은 지킬 박사, 도리안 그레이, 모로 박사 의 이야기와 같은 고딕 소설들을 언급하면서, 이들이 공통적 으로 인간의 야수적 본성과 도덕적 본성의 이중성을 다룬다 고 지적하였다. 그는 배트맨도 이러한 고딕 소설 전통의 연 장선상에 있다고 주장하였다. 어린아이 상태에서 부모를 잃 은 채 언제든 도덕적 방탕함으로 빠질 수 있는 부유한 청년 브루스 웨인에게 배트맨이라는 또다른 정체성은 상실된 아 버지를 보상하여 그를 더욱 도덕적으로 만드는 강력한 초자 아의 역할을 한다. 부모의 상실이라는 외상이 어린 브루스 웨인에게 통제되지 않는 공격성과 성적 욕구를 남겼고, 브루 스는 이것들을 통제하기 위해 배트맨이라는 강력한 보조 자 아 혹은 초자아를 창조했다는 설명이다.

이처럼 브루스 웨인과 배트맨 사이에서 관찰되는 정체성 의 분리를 공격성과 그것을 억제하려는 초자아 사이의 분리 로 사유해 볼 수도 있지만, 다른 관점에서 그것을 취약한 자 기에 의해 유발된 분열의 관점에서 바라볼 수도 있다. 특히 〈배트맨 비긴즈〉에서의 브루스 웨인은 다른 슈퍼 히어로들 에 비해 일관성이 결여되고 응집되지 못한 정체성을 보여준 다. 브루스 웨인은 방탕하고 오만한 부잣집 청년과 밤의 기 
사의 모습 중 어떤 것이 진짜 자신을 규정하는지 혼란스러워 하는 모습을 보인다. "내 안에 있는 어떤 것이 아니라, 내가 무엇을 하느냐가 나 자신을 규정한다(Nolan 2005)."는 그의 항변은 그 자체로 그가 자기 규정의 문제 틀 안에 놓여 있음 을 반영한다. 브루스 웨인은 한편으로 매우 오만하고 버릇없 는 모습을 보여주지만, 다른 한편으로 모두가 부러워할 만한 사회적 지위와 경제력에도 불구하고 공허감과 수치감 및 분 노를 보여준다. 이것은 어린시절 자기(self)가 최적의 좌절을 통해 변형적 내재화를 경험할 기회를 박탈당함으로써 여전히 자기(self)가 응집되지 못한 채 해리된 상태로 남아 있음을 시 사하는 것이다.

Kohut(1971)은 그의 첫번째 저서『자기의 분석」에서 자기 애적 성격에서의 분열에 대해 설명하였다. 아이가 어린 시절 진정한 공감이 결여된 상태로 부모 또는 외부의 과시적인 요구에 맞추어 자신을 형성해 나갈 경우, 아이는 외부의 요 구에 부응하는 과대자기를 형성하게 된다. 이런 경우 아이는 겉보기에 자신만만하고 오만한 모습을 보이지만, 다른 한편 으로 자기 자신의 진짜 모습으로 살아가지 못하는 느낌으로 인해 우울감과 공허감을 갖게 된다. 그는 이처럼 두 가지 모 습이 분열되어 있는 것을 부정(disavowal)을 통한 수직적 분 열(vertical splitting)이라고 불렀다. 한편 이런 환자들의 진짜 자기, 즉 어린 시절 공감받고 성장하지 못한 고태적인 자기 가 억압(repressed)된 채 의식 저편으로 물러서 있는 경우, 이 것을 수평적 분열(horizontal splitting)이라고 불렀다. Kohut (1971)은 이런 사람들에게 먼저 자신의 거짓된 과대자기를 받아들이도록 한 뒤 억압된 고태적 자기가 다시 성장 과정에 들어설 수 있도록 하는 것이 치료의 골자라고 설명하였다.

어린 소년 브루스 웨인은 아무런 준비가 되지 않은 상태 에서 부모의 상실을 맞게 되면서 막대한 재산과 부를 물려 받는다. 공감해 주는 부모 없이 사교계와 사회로부터의 기대 와 요구를 갑작스럽게 받아들여야만 하는 상황은 어린 소년 에게 엄청난 스트레스를 주었을 것이다. 브루스는 명문 학교 에 다니면서 웨인 가문의 체면을 유지할 것을 요구받지만, 그러한 자신의 역할에 적응하지 못하여 결국 학교를 중퇴하 고 고향으로 돌아온다. 외상적 사건의 영향력에서 헤어나오 지 못한 그는 브루스 웨인이라는 정체성을 좀처럼 받아들이 지 못한다. 그를 이끄는 유일한 동기는 분노이지만, 살해범 이 엉뚱한 사람의 손에 살해당함으로써 그 분노마저 제대로 표출하지 못하게 된다. 복수에 실패함으로써 아버지라는 이 상화된 대상의 권위를 회복시키지 못하고 돌아온 그에게 악 당 팔코네(Falcone)는 외상적 사건 당시 브루스 웨인의 아버 지가 개처럼 목숨을 구걸했다고 말하여 브루스 웨인을 참을 수 없는 수치심에 휩싸이게 만든다. 이런 수치심에 대한 반
동으로 브루스 웨인은 신체를 단련시키고, 전능한 힘을 가진 존재가 되려는 환상을 실현하고자 애쓰게 되었을 것이다.

\section{원시적 충동과 정동의 문제}

배트맨의 정동적 측면에서 공격성, 분노, 그리고 공포라는 요소는 매우 중요한 역할을 한다. Bass(2009)는 나쁜 충동 (bad impulse)의 측면에서 이를 다루었다. 그는 브루스 웨인 의 나쁘고 파괴적인 충동들, 그리고 와해시키는 힘들(disintegrating forces)이 양육자를 통해 적절히 담아지지(contain) 못했고, 이런 이유로 간헐적으로 배트맨의 공격성이 드러난 다고 주장했다. Lang(1990)은 공포증 개념을 적용해서 배트 맨이라는 캐릭터 안에 내재된 공포를 다루었다. 그는 배트맨 이 느끼는 공포, 그중에서도 박쥐에 대한 공포는 부모의 상실 에서 기원한다고 하였다. 그는 Freud(1926)처럼 공포증을 신 경증의 근본 형태로 보았는데, 부재하는 아버지를 보완하기 위해 말 공포증을 만들어 냈던 꼬마 한스의 사례처럼, 배트맨 도 박쥐라는 공포증 요소를 도입하였다고 주장했다. Lang은 브루스 웨인이 영원히 해결되지 않는 오이디푸스적 위기 속 에 놓여 있기 때문에 그에게 박쥐라는 상징이 원초경으로서 반복적으로 나타난다고 보았다. 즉 박쥐란 완결되지 못한 거 세가 반복적으로 상연되는 것을 상징한다는 주장이다. 그러 나 자기애적 손상이라는 관점에서 봤을 때 공격성, 분노, 공포 는 모두 자기의 손상에서 자연스럽게 야기되는 심리적 효과 들이라고 볼 수 있다. Kohut(1971)은 자기의 응집성이 와해될 때 개인이 흔히 위의 세 가지 정동들을 보인다고 지적하였다.

먼저 공포라는 정동의 측면에서 이는 자기가 파편화되는 느낌에 상응하는 것이라고 볼 수 있다. Kohut(1971)에 의하 면 자기의 응집성이 떨어질 때 개인은 자기가 파편화되는 공포를 경험하는데, 이런 의미에서〈배트맨 비긴즈〉의 박쥐 는 어떤 면에서 파편화된 자기의 상태를 환기시키는 표상이 라고 볼 수 있다. 어린 시절의 브루스 웨인은 아무도 없는 어 두컴컴한 동굴에서 홀로 박쥐로부터 공격을 당한다. 이는 자 기의 응집성이 매우 저하되었던 시기에 박쥐에 노출되었다 는 것을 의미한다. 이를 반영하듯 브루스 웨인은 배트맨으로 거듭나기 전 가장 취약한 시기, 즉 오지의 감옥에 갇힌 상태 에서 박쥐에 대한 꿈을 꾼다. 브루스의 진짜 자기(true self) 가 언제든 해체될 수 있는 취약한 이미지라면, 박쥐의 이미 지는 강력하고 압도적인 것이다. 박쥐는 고태적인 과대자기 를 활성화시키는 기능을 할 수도 있다. 자기애성 성격의 개 인들은 고태적인 과대자기가 활성화되는 것에 대한 공포를 경험한다고 Kohut(1971)이 지적한 바 있다. 그는 환자들이 꾸는 악몽들, 가령 추락하는 내용의 꿈들이 공중을 날아다니 는 환상들의 이면이라고 본다. 이런 공포는 '떨어지는 꿈으 
로 표현되는 통제할 수 없는 퇴행에 대한 공포, 활성화되는 원시적인 과시로 인한 통제할 수 없는 과도한 자극에 대한 공포, 과대 환상들의 급격한 분출로 인한 현실과의 접촉 상 실에 대한 공포'라고 볼 수 있다는 것이다. 배트맨에게 박쥐 는 하늘을 날아다니는 고태적 환상을 실현시켜 줄 수 있는 매개물이다. 그렇기 때문에 박쥐는 그 자체로 파편화된 자기 를 연상시키기도 하지만, 다른 한편 고태적인 환상의 급격한 분출을 자극함으로써 브루스로 하여금 통제할 수 없는 것에 대한 공포를 느끼게 할 수도 있다.

다음으로 자기의 파편화는 두 가지 측면에서 공격성과 분 노를 야기할 수 있다. 첫째는 자기애적 격노의 형태로 공격 성이 표출되는 것이다. Kohut(1971)에 따르면 '자기애적 평 정이 방해받을 때, 전적인 철수와 무자비한 격노가 혼합된 과도하게 예민한 반응'이 나타나는데, 이는 자기애적 리비도 집중이 방해받을 때 나타나는 구강기적 격노이며, 자기애적 통제감의 박탈에 수반되는 무기력감 때문에 생기는 분노이 다. Kohut(1971)은 특히 이상화된 자기대상과의 자기애적 연합이 상실될 때 발생하는 분노에 대해 여러 차례 언급했 는데, 가령 치료자가 휴가를 가거나 멀리 떨어지게 될 때 자 기애적 환자가 표현하는 분노에 대해 기술하였다. 그는 이런 경우 환자가 과대자기의 확장 혹은 자기대상으로 기능하는 치료자와의 분리에 대해서 좌절을 느낌과 동시에 격노를 경 험한다고 설명하였다. 이런 관점에서 브루스 웨인의 분노는 부모님이 어린 시절 자신을 두고 떠났다는 것 자체에서 유발 되기도 하지만, 그로 하여금 부모님을 더 이상 이상화하기 어렵게 만드는 상황들에 의해 유발될 수도 있다. "너희 아버 지가 목숨만은 살려 달라고 빌었다더군. 마치 개처럼 말이지 (Nolan 2005)."라던 팔코네의 발언은 그의 정신 속에서나마 남아 있던 이상화 부모 이마고를 박탈하는 상황으로 이해할 수 있다. "네 부모님의 죽음은 네 탓이 아니야. 너의 아버지 의 탓이지(Nolan 2005)."라던 라스 알 굴의 말에, 브루스는 스스로가 면죄부를 받았음에도 오히려 참을 수 없는 분노를 느끼는 모습을 보인다. 그에게는 아버지에 대한 비난보다 차 라리 자기 자신에 대한 비난이 더 용납될 만한 것처럼 보이는 데, 이는 그만큼 그에게서 이상화 자기대상을 유지시키는 것 이 중요한 기능을 하고 있다는 것을 보여준다.

둘째는 반사회적 행동화 성향으로 공격성이 나타나는 것 이다. Kohut(1971)의 관점에서 자기애성 성격의 반사회적 성 향은 대체로 '초자아의 결함'에서 기인하는 것이 아니며 '충 동 패턴'에서 기인하는 것도 아니다. 그것은 '과대자기의 억 압된 면이 부분적으로 억압을 뚫고 나옴’으로써 나타나는 증 상이다. 즉, 미숙한 과대자기의 표현이 공격성의 일환으로 해석될 수 있다는 것이다. 이들의 반사회적 행동 또는 비행과
일탈은 한편으로 '자신이 전능하며 행동에 제한을 받지 않는 다는 것을 과시하는 것'이며, 다른 한편으로 이는 '상실한 이 상화 자기-대상을 열망하고 있다는 사실을 인식하는 것에 대한 하나의 방어이며, 또한 환자 자신의 과대자기의 상상적 인 말과 행동이 끝날 때 그를 지배하는 공허감과 자존감 결 핍에 대한 방어'라는 것이다(Kohut 1971). 〈배트맨 비긴즈〉 속에서 배트맨은 텀블러(배트맨의 자동차)를 타고 도시를 종 횡무진하는 가운데 도로, 주택 같은 기반 시설들을 막무가내 로 파괴하고 다니는 경향을 보인다. 이 때문에 〈배트맨 비긴 즈〉의 후속작인 〈다크 나이트>에서는 이처럼 치외법권적인 특징이 시민들의 분노를 자극하기도 한다. 어떤 면에서 그의 행동은 일견 반사회적인 것처럼 느껴지기도 하는데, 이를 법 에 대한 개념 또는 초자아 기능의 결여로 귀인하는 것은 다 소 무리가 있어 보인다. 배트맨은 분명 "배트맨이 없이도 돌 아갈 수 있는 사회'에 대한 열망을 표현하고 법치도시를 꿈 꾸기 때문이다. 이처럼 법에 대한 존중이 비교적 온전한 자 아 및 초자아 기능과 양립되어 나타나는 폭력적 성향을 고태 적인 자기의 과시적인 차원에서 야기되는 것으로 해석하는 편이 보다 설득력을 갖는다. 배트맨은 모든 악당들을 공포에 떨게 만드는 위대하고 강력한 존재가 되기를 갈망함과 동시 에 어떠한 법 체계로부터도 제한받지 않는 과시적인 자기를 드러내는 것이다. 〈배트맨 비긴즈〉의 한 장면에서 어느날 밤 알프레드가 다가와 텔레비전을 가리키면서 브루스를 힐난한 다. "주인님 안의 괴물 때문에 정신을 못 차리고 계신 것 같 네요(Nolan 2005).” 이에 대해 브루스는 자신은 다만 그 괴물 을 이용해 아버지처럼 사람들을 도우려고 할 뿐이라고 항변 한다. 그러자 알프레드가 말한다. "토마스 주인님에게 남을 돕는다는 건 뭔가 보여주기 위한 게 아니었어요. 그 자신을 포함해서요(Nolan 2005)."

\section{환상의 문제와 고태적 환상}

PDM-2(Malberg와 Rosenberg 2017)는 외상을 입은 소아 들에게서 도피적인 환상들이 발생한다는 점을 지적하면서, 이것이 나이에 걸맞지 않은 사고를 동반한다고 하였다. Lang (1990)은 외상 이후 아이들이 모든 것을 외상 이전의 상태로 되돌리는 마술적인 환상을 갖거나, 심지어 자신이 사실은 위 대한 부모에게서 태어난 자녀라는 환상을 가질 수 있다고 하 였다. Brody(1995), Reichstein(1998), Langley(2012)는 모두 소년 브루스 웨인에게서 제대로 해소되지 못한 채 억압된 부친 살해 환상에 대해 이야기하면서, 이것이 다양한 방어기 제를 거쳐 배트맨의 여러 특질을 형성한다고 주장하였다. 그 런데 이처럼 미숙한 환상은 자기의 발달이라는 관점에서, 즉 억압된 과대자기가 가진 환상의 행동화라는 측면에서 바라 
볼 수도 있다. Kohut(1971)은 적절하게 성숙되지 못한 자기 에서 '과대자기는 적절한 자아 내용으로 융합되지 못하고 변 화되지 않은 채로 남게 되며, 원초적인 목적들을 성취하려는 시도를 하게 된다'고 하였다. 즉, 자기가 적절히 성숙되지 않 은 경우 개인은 유아적이고 마술적인 환상을 실현하려 하거 나, 그런 과정에서 무모한 행동을 저지르게 된다는 것이다. < 배트맨 비긴즈> 속의 배트맨에게서도 이러한 환상들을 관찰 할 수 있다.

첫째는 공중을 날아오르는 유아적 환상이다. 〈배트맨 비 긴즈>는 배트맨에 대한 그 어떤 판본들보다 그가 어떻게 현 실적으로 날 수 있게 되었는지를 묘사하는 데 많은 부분을 할 애한다. 브루스 웨인은 전류가 흐르면 모양을 바꾸는 케블라 섬유를 보며 감탄하고, 이를 이용해 날개의 기능을 할 수 있는 망토를 만든다. 영화 속에서 배트맨이 커다랗게 망토를 펼치 고 도시 위를 활강하는 모습은 보는 이들로 하여금 짜릿한 쾌 감을 느끼게 만든다. "가구 위에서 뛰어내리고 문 밖으로 뛰어 오르려는 충동을 느끼는 많은 아이들처럼, 나는 배트맨이 되 고 싶어 목욕 수건을 목에 두르고 다녔죠.”라던 Novy(2008)의 고백처럼, 아이들은 하늘을 날 수 있는 슈퍼 히어로들의 모습 에 쉽게 매료된다. 박쥐를 형상화한 배트맨의 모습 속에는 분명 아이들의 원초적인 환상을 자극하는 면이 있는 것으로 보인다. Kohut(1971)에 따르면 '공중을 날아오르는 환상은 일반적으로 수정되지 못한 유아적 과대주의의 특성을 나타 내는 것'이다. Kohut(1971)의 많은 자기애적 환자들이 종종 '슈퍼맨이 되어 하늘을 나는 꿈’을 보고했는데, 그는 높은 곳 에 올라가거나 그곳에서 뛰어내리는 위험한 행동이 나타나 는 이유를 미숙한 과대자기에서 기원하는 것으로 보았다. 즉, 과대자기가 직접적으로 활성화되면서 전능함을 과시하 기 위해 이런 경향이 나타난다고 설명하였다.

둘째는 마술적 통제력을 가진 전능함에 대한 환상이다. 사 실 배트맨은 마술적인 것과 가장 거리가 멀어 보이는 캐릭터 이다. Brody(1995)가 지적했듯 '슈퍼맨과 달리, 이 영웅은 인 간적이고 취약'하며, '피를 흘리고, 상처받는다'. 배트맨은 자 신의 막대한 부와 기술력을 이용해 자신의 인간적 취약성을 보완하며, 그런 면에서 과학 기술에 기반한 현대인의 모습을 가장 잘 대변한다고 볼 수 있다. 하지만 이렇게 현대적이고 도시적인 배트맨의 서사 구조 안에도 환상적이고 마술적인 면이 등장하는데, 라스 알 굴은 이런 면을 보여주는 가장 대 표적인 캐릭터라고 할 수 있다. 다른 배트맨 영화들에 비해 현실적인 측면에 집중했던 〈배트맨 비긴즈〉에서 라스 알 굴 의 불멸성은 일종의 비유로 표현되지만, 사실 오리지널 코믹 스에서 그는 실제로 거의 영생에 가까운 삶을 누리는 자로 나온다(Taylor 2008). 〈배트맨 비긴즈〉 속의 브루스 웨인은
라스 알 굴의 가르침을 받고자 깊은 산속으로 들어가 흡사 밀교적인 수련에 임한다. 물론 영화는 실제적인 전투 기술이 나 은닉 전략 등을 보여주며 이를 비교적 현실적 차원으로 해석하고 있지만, 중요한 것은 영화의 전체 맥락에서 브루스 웨인 자신이 그처럼 마술적 통제력을 가진 전능함에 대한 갈망을 드러낸다는 것이다. Kohut(1971)은 이러한 과대 환 상에 대해 말하면서, 이런 환상을 가진 사람들의 예로 히틀 러와 훈족의 아틸라를 들고 있다. 이어서 그는 이런 지도자 들에게 '그들의 마술적 통제를 받는 많은 대중들이 있었는 데, 그들은 그 대중들을 마치 생명 없는 기계 뭉치처럼 대했 다'고 하였다.

셋째는 강력한 힘을 가진 완벽한 신체에 대한 환상이다. 여기서 강력한 힘을 가진 완벽한 신체의 중심에는 박쥐의 상징이 자리잡고 있다. Lang(1990)은 쾌걸 조로의 사례를 들 면서 Z라는 마크의 반복을 남근적인 의미로 해석한 바 있다. 조로의 표식 자체가 오이디푸스 콤플렉스의 해소를 상징한 다는 것이다. 비슷한 관점에서 박쥐와의 동일시를 공격자와 의 동일시의 일종으로 해석할 수도 있다. Freud(1937)는 죄 책감을 느끼게 만드는 어른들의 공격성을 내사하고, 수동적 역할을 능동적 역할로 바꾸는 전략으로서의 동일시 개념을 소 개한 바 있다. 만약 박쥐가 거세하는 아버지를 대변하고, 공포 증적 요소로서 기능한다면 박쥐와의 동일시는 곧 공격자와의 동일시에 상응하는 것으로 해석할 수도 있다. 그러나 Kohut (1971)은 실제로는 자기애적 속성을 가진 동일시임에도 불구 하고 겉보기에 공격자와의 동일시처럼 보일 수 있는 경우에 대해 언급하면서 양자 사이의 구별이 중요함을 주장한 바 있 다. 실제로 배트맨에게서 날개를 가진 박쥐라는 상징물은 단 순히 처벌적인 속성을 가진 것을 넘어, 무너지지 않는 강력한 존재를 대변하는 것으로 보인다. 박쥐라는 상징을 묘사하는 과정에서 브루스는 “왜 하필 박쥐인가요?(Nolan 2005)."라는 알프레드의 질문에, "인간의 수준에서, 나는 피와 살이고, 따 라서 무시되거나 파괴될 수 있는 존재죠. 그러나 하나의 상 징으로서, 나는 불멸의 존재가 될 수 있어요. 영원히 존재할 수 있는 거죠(Nolan 2005).”라고 말한다.

지금까지 배트맨에서 나타나는 과대 환상들을 다루어보 았다. 여기서 흥미로운 점은 두 번째와 세 번째 환상에서 관 찰되듯이 과대자기가 흔히 이상화할 대상을 전제하고 있다 는 것이다. 두 번째 환상에서 배트맨은 자신이 마법적 통제 력을 갖고자 함과 동시에 그런 힘을 빼앗을 수 있는 강력한 존재인 라스 알 굴을 필요로 하였다. 세 번째 환상에서 배트 맨은 강력한 힘과 완벽한 신체를 가진 존재가 되기 위해 박 쥐라는 상징물을 필요로 하였다. 이처럼 과대자기와 이상화 가 모두 필요하다는 것은 언제나 고태적 과대자기와 이상화 
부모 이마고의 양극으로 자기(self)가 발달된다는 자기의 발 달 이론에 자연스럽게 귀결된다.

\section{관계의 문제와 이상화 자기대상 요구}

그동안 배트맨을 다룬 정신분석 문헌에서는 대체로 브루 스 웨인과 여성들 사이의 이성애적 차원에서 또는 배트맨과 로빈 사이의 동성애적인 차원에서 관계의 문제를 다루었다. 정신과 의사인 Wertham(1972)이 그의 저서『순수에의 유혹』 에서 배트맨과 로빈 사이의 동성애적 관계에 대해 기술하면 서 그것이 청소년에게 미칠 잠재적 위험을 지적한 이후로 많 은 저자들이 유사한 주제에 천착해 왔다. Lang(1990)은 조기 모성 상실이라는 관점에서 배트맨의 동성애 문제를 다루었 다. 그는 브루스 웨인이 오이디푸스기 갈등을 적절히 해소하 지 못하여 자기애적인 단계에 머문다고 주장하였다. 브루스 웨인에게 여성이란 아동기의 취약성을 상기시키는 불편한 요소이며 따라서 배트맨은 여성을 기피함으로써 자신의 자 립성을 강화하는 한편 자기애적인 차원에서 어린 고아 소년 인 로빈을 사랑할 수밖에 없다는 설명이다. 또한 그는 상실 된 모성의 기능을 대신하는 차원에서 알프레드와 배트맨 사 이의 돈독한 관계를 기술하기도 하였다. 이에 반해 Reichstein(1998)은 로빈과 배트맨 사이의 관계를 동성애적인 것 으로 보기보다는 아들과 아버지 관계의 반복으로 보았다. 즉 배트맨이 로빈을 통해 스스로 아버지의 기능에 동일시함으 로써 자신의 상실을 극복한다는 주장이다.

〈배트맨 비긴즈〉 속에서도 우리는 상대적으로 남자 인물 들이 더 부각되는 것을 볼 수 있다. 아버지 토마스 웨인에 비 해 어머니 마사 웨인은 대사가 한 마디 남짓밖에 없을 정도 로 비중이 작은 편이며, 유일하게 존재감이 있는 여성인 레 이첼의 경우 배트맨의 단짝 친구이자 훗날의 연인으로 묘사 되는데, 영화는 둘의 사랑은 그다지 비중 있게 다루지 않는 다. 이에 대해 Wertham이나 Lang의 입장을 참조하여 배트 맨에게 동성애적 성향이 더 우세하기 때문이라고 생각하거 나, 배트맨의 성장기를 다뤄야 하는 영화적 내러티브의 목적 상 그럴 수밖에 없다고 볼 수도 있다. 그러나 영화의 전체 구 조를 배트맨의 손상된 자기와 그 회복 과정으로 간주한다면, 남성적인 인물들이 더 비중 있게 다루어지는 이유를 다르게 해석할 수 있다. 즉, 브루스 웨인의 손상된 자기가 필요로 하 는 자기대상의 기능들이 부각되면서 상대적으로 로맨틱한 관계의 비중이 줄어들었다고 보는 것이다.

Zepinic(2016)과 Hagman(2016)은 모두 자기의 성숙과 발 달에서 타인과의 상호관계가 중요함을 이야기하는데, 특히 Hagman은 자기의 발달이 자기대상과의 끊임없는 상호작용 을 통해 타인의 주관성을 상호 인정하는 단계에 도달해야 한
다고 지적하였다. 어린 시절 자기대상 연대를 공유했던 부모 가 사망하는 사건은 아이에게 매우 외상적인 결과를 초래하 고, 아이의 자기(self)는 타자를 인정하는 것으로부터 후퇴해 서 Kohut(1971)이 이야기한 고태적 자기-자기대상 관계로 되돌아가는 경향을 보이게 된다. 이런 경우 아이는 강하고 완 벽해 보이는 이상화 자기대상과 융합을 갈망하게 된다. $\mathrm{Ko}^{-}$ hut(1971)은 자기애적 문제가 있는 환자들에서 초자아는 불 완전하게 이상화되며, 따라서 그들은 '비록 자신 안에 가치 와 가치에 대한 기준을 지니고 있다 하더라도 외부의 이상적 인물들을 끊임없이 추구하게 되며, 그것을 통해서 자신의 초 자아가 제공해 주지 못하는 확인과 지도를 구하려' 한다고 지적하였다. 우리는 〈배트맨 비긴즈〉에서 한편으로 타인에 대한 의존 및 타인으로부터의 도움을 거절하고 그들을 평가 절하하면서 다른 한편으로 특정한 인물들을 마술적으로 이 상화하는 브루스 웨인의 모습을 볼 수 있다. 감옥에 갇힌 브 루스를 찾아와 가르침을 받아보지 않겠느냐며 열심히 설명 하는 라스 알 굴을 보며 브루스는 처음에 "민간 치안대군 (Nolan 2005)”이라고 말하며 콧방귀를 뀌는 모습을 보인다. 그러나 곧 라스 알 굴이 인간의 한계를 벗어나 전설이 되는 방 법을 알려주겠다고 하자 금새 표정을 바꾸며 호기심을 보인 다. 이후 자신을 찾아온 브루스 웨인에게 라스 알 굴은 "600명 을 대적하는 방법(Nolan 2005)”을 가르쳐 주겠다고 말하는가 하면, "진정 눈에 보이지 않게 사라지는 방법(Nolan 2005)"을 알려주겠다고 하며 브루스 웨인의 이상화 욕구를 자극한다. 이에 더해 앞서 기술한 동성애적 주제와 관련하여 이처럼 강 력한 자기대상과의 융합을 갈망하는 경향이 표면상 동성애 적인 것으로 나타날 수도 있다는 점을 염두에 둘 필요가 있 다. 실제로 Kohut(1971)은 『자기의 분석』에서 동성애적 성향 을 보였던 환자 $\mathrm{A}$ 에 대해 설명하면서, 그가 '완전하고 강한 이상적인 인물'로부터 힘을 빼앗아 가짐으로써 일시적으로 자기애적 균형감을 얻고자 했으며, 아버지의 부재 동안 아무 런 도움도 받을 수 없는 압도하는 외부 환경에 대처하기 위 해서 종종 '전능한 자기-대상을 재생시키려는 욕구'를 강화 시켰다고 지적한 바 있다.

고태적 자기대상으로 후퇴하는 것은 브루스 웨인으로 하 여금 환상적인 아버지를 재구성하고 유지해야만 하는 필요 성을 야기하기도 한다. 브루스 웨인의 아버지 토마스 웨인은 정의로운 데다가 용기를 가진 인자한 박애주의자로 나타난 다. 브루스 웨인에게 아버지는 그의 자기가 필요로 하는 자 기대상으로서의 이상화 부모 이마고에 가까운 존재이다. 이 는 자기애적 환자들이 반드시 유지해야만 하는 훌륭한 아버 지의 모습을 대변한다. Kohut(1971)은 2차 세계대전 동안 아버지를 잃은 아이들에게서 관찰되는 환상적 아버지의 테 
마에 대해 다루면서, 이런 현상이 항상 병리적인 것은 아니 라는 점을 염두에 두어야 한다고 강조하였다. Kohut(1971) 은 자기가 발달하는 과정에서 이상화된 부모 이마고가 매우 중요한 기능을 담당하며, 필수적인 요소라고 하였다. 그것 없이 자기가 발달할 수 없으며, 그 자체가 이미 자기의 일부 이기 때문에 그것 없이 자기라는 개념 자체가 불가능하다는 것이다. Kohut(1971)은 자기애적 환자들이 이상화된 아버지 를 유지해야 하는 압력이 큰 나머지 훌륭한 아버지상을 거 짓으로 만들어내는 경우도 있다고 지적하였다. 배트맨에게 역시 환상의 아버지는 매우 중요한 존재로 나타난다. 라스 알 굴과 팔코네가 아버지 토마스 웨인을 평가절하하는 발언 을 할 때 브루스 웨인이 보이는 엄청난 분노는 그에게 더럽 혀지지 않은 아버지를 유지하는 것이 얼마나 중요한 것인지 잘 보여준다.

조기에 상실된 아버지로 인해 환상 속에 이런 아버지가 자 리잡고 있다면, 현실 속에는 고든 청장과 알프레드가 존재한 다. 부모의 장례식장에서 스스로를 자책하고 있는 브루스 웨 인을 가장 먼저 안아 주는 것은 알프레드이다. 문자 그대로 안 아 주는 환경(holding environment)으로써 알프레드의 기능 을 보여주는 장면이다. 그는 부모님을 잃은 브루스 웨인에게 삶의 지침을 제공해 주고 지도하는 유일한 대체 양육자의 역 할을 한다. 배트맨은 종종 자신을 꾸짖는 알프레드와 반목을 겪기도 하지만, 그가 가장 취약한 상태에 놓이는 순간 언제나 알프레드를 찾는다. 스케어크로우의 공격을 받는 순간 배트맨 이 가장 먼저 찾는 것은 알프레드이고, 불타는 집에서 그가 알프 레드에게 하는 말은 "나를 여전히 포기하지 않았나요?(Nolan 2005)"라는 말이다. 알프레드는 심지어 브루스가 토마스 웨인 의 지인들에게 모욕적인 발언을 하면서 가문의 명예에 흠집 을 내거나 자동차를 타고 지붕 위를 넘나들며 위험천만한 행 동을 해도 그의 곁을 떠나지 않고 항상 그를 지지해 주고 반 영해 준다.

고든과 폭스는 배트맨의 과대 환상과 관련해 또다른 자기 대상으로 작용한다. 고담시에서 유일하게 부패하지 않은 고 든 청장은 정의라는 측면에서 토마스 웨인을 가장 많이 닮 은 사람이다. 토마스 웨인 사후에 고담시는 점점 타락하고 범죄의 온상이 되지만 고든만은 그런 것에 휩쓸리지 않고 정의와 도덕의 가치를 좇는다. 또한 배트맨이 악당을 사로잡 을 때마다 언제나 고든이 나타나 그의 활극을 지켜봐 준다. 브루스가 배트맨으로서 처음 등장했을 때, 악당 팔코네를 잡 고 난 뒤 그를 조명등에 매닮으로써 자신의 업적을 과시하 는 장면에서 고든 청장은 이를 감탄하며 바라봐 준다. 배트 맨은 항상 자신이 어떤 계획을 갖고 있는지 고든에게 이야기 하고, 고든은 그의 계획에 동참해 준다. 이는 자기애적 환자
에게 공감적으로 반응하는 치료자의 역할과 매우 비슷하다. 고든은 그의 행동을 비판하고 비난하는 대신, 그가 자신의 과대한 꿈을 이야기하는 것을 반영해 주고 들어주는 역할을 한다. 이는 마치 “엄마 나는 날 수 있어요”라고 말하는 어린 이의 과대적인 환상을 어머니가 반영해 주는 기능을 닮았다. 과학부장 폭스도 비슷한 반영의 자기대상 기능을 한다. 배트 맨은 악을 궤멸한다는 자신의 대의를 이루기 위해 과학이라 는 수단에 기대는데, 다양한 과학 기술에 대한 관심을 보이 며 탐구 행위를 이어간다. 여기서 부모의 관심 아래 과학 실 험에 물두 중인 자녀의 이미지가 겹쳐진다. 배트맨은 끊임없 이 새로운 과학 실험을 하고, 폭스는 그런 배트맨에게 아낌 없는 지원을 해 준다. 폭스는 사물을 다루고 통제하고 학습하 고자 하는 배트맨에게 학습을 지도하는 어머니의 모습을 담 당한다.

요약하면 자기-응집성에 심각한 장애가 발생했을 때 개인 은 고태적 자기대상과 연합을 쉽사리 끊으려 하지 않으며, 완벽한 과대자기와 전능한 이상화 부모의 이미지를 지켜내 려고 시도한다. 따라서 그들의 환상 속에서 완벽한 과대자기 와 전능한 아버지를 유지하는 것은 중요한 문제가 되며, 브 루스 웨인의 경우에서도 같은 문제가 드러난다. 어린 시절 부모 상실로 취약한 자기(self)에 머무르는 브루스 웨인은 언 제나 자신을 반영해 주고 이끌어 줄 자기대상을 필요로 하는 데, 영화 속 인물 알프레드, 고든, 폭스는 이런 자기대상 기능 을 제공한다. 이처럼 자기대상의 기능이 주된 주제가 되는 자기애의 문제에서는 성적인 대상관계보다 자기-응집성을 회복하는 것이 더 중요한 문제로 간주되기 때문에 상대적으 로 여성과의 로맨스는 그 비중이 덜 강조되며, 이것이 표면 상 동성애를 시사하는 것처럼 보일 수도 있다.

\section{결 론}

본 논문은 지금까지〈배트맨 비긴즈〉라는 영화 속에 묘사 된 배트맨이라는 캐릭터를 소재 삼아 부모의 상실이라는 외 상이 자기의 발달에 미치는 효과를 살펴보았다. 이전까지의 논문들은 주로 외상과 그로 인한 자아 취약성 그리고 방어기 제를 중심으로 배트맨의 특성들을 다루었으나, 본 논문에서 는 외상으로 인한 자아-응집성의 와해 및 그로부터 야기되 는 원초적인 정동들, 미숙한 환상, 분열과 정체성 혼란, 이상 화 등의 문제들에 대해서 살펴보았다.

Kohut(1971)은 그의 저서 곳곳에서 환자를 치료할 때 오 이디푸스적인 갈등이 자기애적인 문제를 시야에서 가릴 수 있으므로 주의할 필요가 있다고 강조하였다. 만약 문제가 자 기의 발달 및 그에 대한 외상에 있다면 치료는 억압된 충동 
및 정동과 방어를 명료화하고 해석하는 것이 아니라 성장을 멈춘 자기의 이상화 및 반영의 욕구를 이해하고 공감하는 방 향으로 나아가야 한다는 주장이다. 이런 관점에서 본 논문은 자기심리학적 관점에서 배트맨을 분석함으로써 표면상 신경 증적 공포증과 오이디푸스적 갈등을 가진 환자라 할지라도 자기의 발달이라는 차원에서 새롭게 조망할 수 있다는 가능 성을 보이고자 하였다.

본 논문의 한계는 첫째로 고전적인 Kohut의 이론에 의지 함으로써 현대의 발전된 자기심리학 및 상호주관성 이론들 의 맥락을 포괄적으로 다루지 못했다는 것이다. 둘째는 배트 맨의 자기대상 요구만을 다룸으로써 배트맨 이외의 다양한 인물들에 대해서는 분석하지 못했다는 것이다. 이런 점들은 이후의 연구 과제들로 남겨두어야 할 것으로 보인다.

\section{Acknowledgments}

None

\section{Conflicts of Interest}

The authors have no potential conflicts of interest to disclose.

\section{Author Contributions}

Conceptualization: Jae Yoon Jeong, Kang Joon Lee, Hyun Kim, Jun-Seok Lee. Data curation: Jae Yoon Jeong, Kang Joon Lee, Hyun Kim, Jun-Seok Lee. Investigation: Jae Yoon Jeong, Kang Joon Lee, Hyun Kim, Jun-Seok Lee. Methodology: Jae Yoon Jeong, Kang Joon Lee, Hyun Kim, Jun-Seok Lee. Project administration: JunSeok Lee. Resources: Jae Yoon Jeong, Kang Joon Lee, Hyun Kim, Jun-Seok Lee. Supervision: Jun-Seok Lee. Validation: Jae Yoon Jeong, Kang Joon Lee, Hyun Kim, Jun-Seok Lee. Writing - original draft: Jae Yoon Jeong, Kang Joon Lee, Hyun Kim, Jun-Seok Lee. Writing — review \& editing: Jae Yoon Jeong, Kang Joon Lee, Hyun Kim, Jun-Seok Lee.

\section{ORCID iDs}

Jun-Seok Lee https://orcid.org/0000-0003-1108-8661

Jae Yoon Jeong https://orcid.org/0000-0002-9207-3738

\section{REFERENCES}

Bass SR. Batman: the Dark Knight directed by Christopher Nolan Warner Brothers, 2008, 152 min. Fort Da 2009;15:119-133.

Beiser HR. The effect of early father loss on the artists work: Charles Burchfield. In: Winer JA. The annual of psychoanalysis. London: Routledge;2013. p.203-214.

Blum HP. Splitting of the ego and its relation to parent loss. J Am Psychoanal Assoc 1983;31S:301-324

Breuer J, Freud S. On the psychical mechanism of hysterical phenomena.
The standard edition of the complete psychological works of Sigmund Freud, Volume II (1893-1895): studies on hysteria. London: Hogarth Press; 1893. p.1-17.

Brody M. Batman: psychic trauma and its solution. J Pop Cult 1995;28: 171-178.

Freud A. The ego and the mechanisms of defence. London: Hogarth Press;1937. p.109-121.

Freud S. Inhibitions, symptoms and anxiety. SE 20. London: Hogarth press; 1926. p.87-172.

Hagman G. Flight from the subjectivity of the other: pathological adaptation to childhood parent loss. In: Goldberg AI. Progress in self psychology: basic ideas reconsidered. London: Routledge;2013. p.207-219.

Kang TU, Yu J. Father in the movie 'Guardians of the galaxy Vol. 2'. Psychoanalysis 2019;30:9-17.

Kohut H. The analysis of the self: a systematic approach to the psychoanalytic treatment of narcissistic personality disorders. Chicago, IL: University of Chicago Press; 1971.

Kohut H. The restoration of the self. New York, NY: International University Press; 1977.

Lang R. Batman and Robin: a family romance. Am Imago 1990;47:293319.

Langley T. Batman and psychology: a dark and stormy knight. Hoboken, NJ: John Wiley \& Sons;2012.

Malberg N, Rosenberg L. Event and stressor related disorders. In: Lingiardi V, McWilliams N. Psychodynamic diagnostic manual: PDM-2. New York, NY: Guilford Publications, Inc.;2017. p.564.

Mahler MS. The psychological birth of the human infant: symbiosis and individuation, 1st ed. London: Hutchinson;1975.

McDougall J. Parent loss. In: Rothstein A. Workshop series of the American Psychoanalytic Association, Monograph 2. The reconstruction of trauma: its significance in clinical work. Madison, CT: International Universities Press, Inc.;1986. p.135-151.

McWilliams N. Psychoanalytic diagnosis: understanding personality structure in the clinical process, 2nd ed. New York, NY: Guilford Publications, Inc.;2011.

Mitchell SA, Black MJ. Freud and beyond: a history of modern psychoanalytic thought. New York, NY: BasicBooks;1995. p.155.

Nolan C. Batman begins. Burbank, CA: Warner Home Video;2005.

Novy R. What is it like to be a Batman? In: Irwin W, White MD, Arp R. Batman and philosophy: the dark knight of the soul. Hoboken, NJ: John Wiley \& Sons, Inc.;2008. p.167-179.

Reichstein A. Batman-An American Mr. Hyde? Amerikastudien 1998;43:329-350.

Stolorow RD. Emotional disturbance, trauma, and authenticity: a phenomenological-contextualist psychoanalytic perspective. In: Aho K. Existential medicine: essays on health and illness. London: Rowman \& Littlefield International;2018. p.17-25.

Taylor RB. Keeping it real in Gotham. In: O'Neil D, Wilson L. Batman unauthorized: vigilantes, jokers, and heroes in Gotham city. Dallas, TX: BenBella Books, Inc.;2008. p.7-9.

Wertham F. Seduction of the innocent. New York, NY: Rinehart;1972. p.173-194.

Zepinic V. Disintegration of the self-structure caused by severe trauma. Psychology and Behavioral Sciences 2016;5:83-92. 